EESTI NSV TEADUSTE AKADEEMIA TOIMETISED. 32. KOIDE GEOLOOGIA. 1983, NR. 4

ИЗВЕСТИЯ АКАДЕМИИ НАУК ЭСТОНСКОИ ССР. ТОМ 32 ГЕОЛОГИЯ. 1983, N. 4

\title{
БРАХИОПОДЫ РОДА DICOELOSIA ИЗ СИЛУРА ПРИБАЛТИКИ
}

Описываемая ниже коллекция рода Dicoelosia состоит более чем из тысячи экземпляров хорошей сохранности в основном из лландовери, венлока и низов лудлова Литвы (рис. 1). Установленные здесь виды, за исключением одного нового, идентифицируемы с известными видами Dicoelosia из силура Великобритании, Норвегии и о-ва Готланд (Wright, 1968; Bassett, 1972), Әстонии и Латвии (Rubel, 1971) и Чехословакии (Havliček, 1977). Однако следует отметить, что как описываемая, так и собранная в последние годы коллекция из силура Прибалтики (всего около 3000 точно увязанных с разрезами экземпляров Dicoelosia) позволяют несколько подробнее осветить изменчивость этих видов. Поэтому было начато их изучение на популяционном уровне. Результаты соответствующей математической обработћки дали возможность обосновать и описанные ниже виды.

Описанные экземпляры, как и числовые данные, хранятся в Институте геологии АН ЭССР в Таллине (каталоговые номера экземпляров начинаются буквами $\mathrm{Br}$ ) и в Геолого-минералогическом музее Вильнюсского государственного университета (коллекция № 14). Используемые стратиграфичеокие подразделения приняты согласно унифицированным схемам силура Прибалтики (Решения..., 1978).

Авторы глубоко признательны И. Ю. Пашкявичюсу (Вильнюс), М. Рубелю (Таллин), О. И. Никифоровой и Т. Л. Модзалевской (Ленинград), П. Д. Цегельнюку (Киев) как за предоставленную возможность изучать коллекции брахиопод из силура Прибалтики, Подолии и о-ва Готланд, так и за многие полезные советы в ходе проведения работы. Авторы выражают благодарность М. .Бассетту (Кардифф, Великобритания) и Г. Баарли (Осло, Норвегия) за представленный топотипический материал по виду Dicoelosia osloensis. Мы весьма признательны и фотографу Института геологии АН ЭССР У. Веске за все снимки.

\section{Вопросы таксономии}

Предполагается, что в течение существования рода Dicoelosia ero paковина изменялась от вогнуто-выпуклой к двояковыпуклой (Amsden, 1968; Wright, 1968). На основе этого недавно были классифицированы и прибалтийские Dicoetosia (Rubel, 1971). Однако несколько позже описанные виды Dicoelosia parvifrons и $D$. diversifrons соответственно из венлока и лудлова Северной Америки (Johnson, и др., 1976) явно отклоняются по форме раковины от предполагаемой линии развития для рассматриваемого рода. Дополнительный материал по прибалтийским Dicoelosia так же показал, что нет строгой однонаправленности в изменении выпуклости их спинных створок (см. ниже). Поэтому использование однонаправленных во времени изменений в форме раковины Dicoelosia как в целях стратиграфических корреляций, так и для их классификации не всегда оправдывается. 
Рис. 1. Схема местоположений скважин. Крякянава-7 (1); Гелува-99 (2); Суткай-87 (3); Пренай-3 (4); Вирбалис-5 (5); Калвария-2 (6); Буткунай-241 (7); Твярячюс-336 (8).

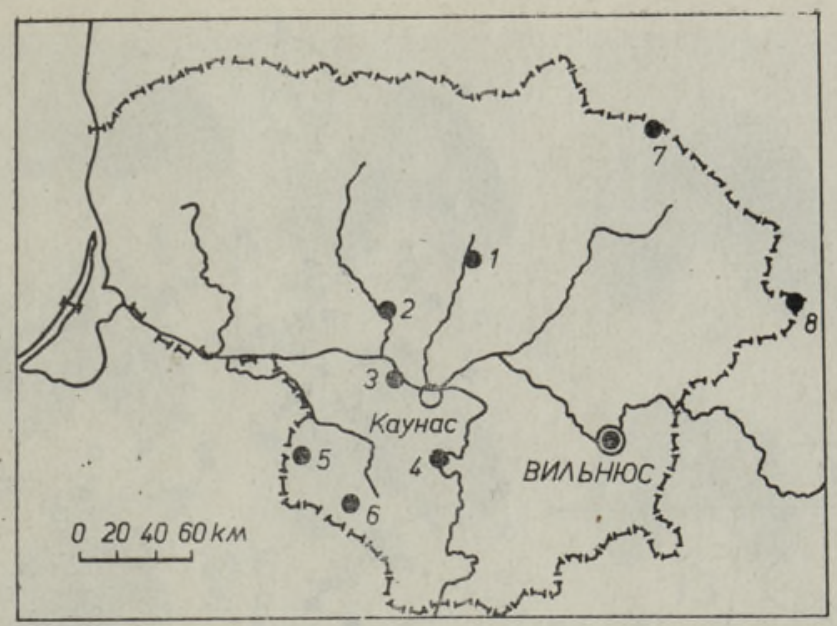

Так, по изученной коллекции, исключительно вогнуто-выпуклые раковины отмечались лишь у раннелландоверийских Dicoelosia c длинными лопастями. Но уже позднелландоверийский вид $D$. paralata далеко неоднозначно отличим по этому признаку от его предполагаемого предка $D$. baltica sp. n. (см. описание). Зато у вида $D$. biloba (Linnaeus) в принятом нами понимании в условиях несомненной стратипрафической последовательности его выборок, отмечалась постепенная смена вогнуто-выпуклых раковин двояковыпуклыми, причем эта смена повторялась несколько раз во многих разрезах. При этом наиболее позднне (лудловские) раковины D. biloba действительно почти равно двояковыпуклые но, следуя сказанному выше, мы воздерживаемся от их идентификации с видом D. oklahomensis (cp. Rubel, 1971).

По-видимому, признаком, развивающимся направленно во времени, можно считать не вогнутость или выпуклость спинной створки целиком, а лишь характер поперечного сечения ее лопіастей. Так, начиная с позднелландоверийского вида $D$. paralata и моложе, это сечение выпуклое, независимо от степени вогнутости спинной створки. Судя по фотографиям, выпуклое поперечное сечение лопастей имеют и вышеупомянутые виды $D$. diversifrons и $D$. parvifrons с вогнутыми спинными створками.

Для прибалтийских раковин $D$. biloba характерна вогнутость боковых краев около замочных углов, что позволяет легко отличать их от стратипрафически непосредственно ниже распространенных раковин вида $D$. paralata с почти прямыми или слабо округленными боковыми краями. Округленные боковые края характерны и для молодых раковин D. paralata в то время как у молодых экземпляров нового вида $D$. baltica sp. n., распространенных стратиграфически ниже $D$. paralata, боковые края около замочных углов опять становятся слабовогнутыми. Вогнутость боковых краев характерна также наиболее древним взрослым раковинам из силура Прибалтики, описанным ранее как D. aff. osloensis (Rubel, 1971, p. 51, pl. 8, figs 18-25). Следует отметить, что в данной работе к этой форме отнесены и среднелландоверийские Dicoelosia, по общей форме раковины неотличимые от венлокских экземпляров D. biloba.

Характер ребристости на синусах обеих створок определяли исключительно визуально. По изученному материалу трудно оценить диагностическое значение этого не всегда наблюдаемого признака. Отметим только, что многие раннелландоверийские створки Dicoelosia из силура Прибалтики характеризуются присутствием более чем одного-двух мелких -ребрышек на синусах. 


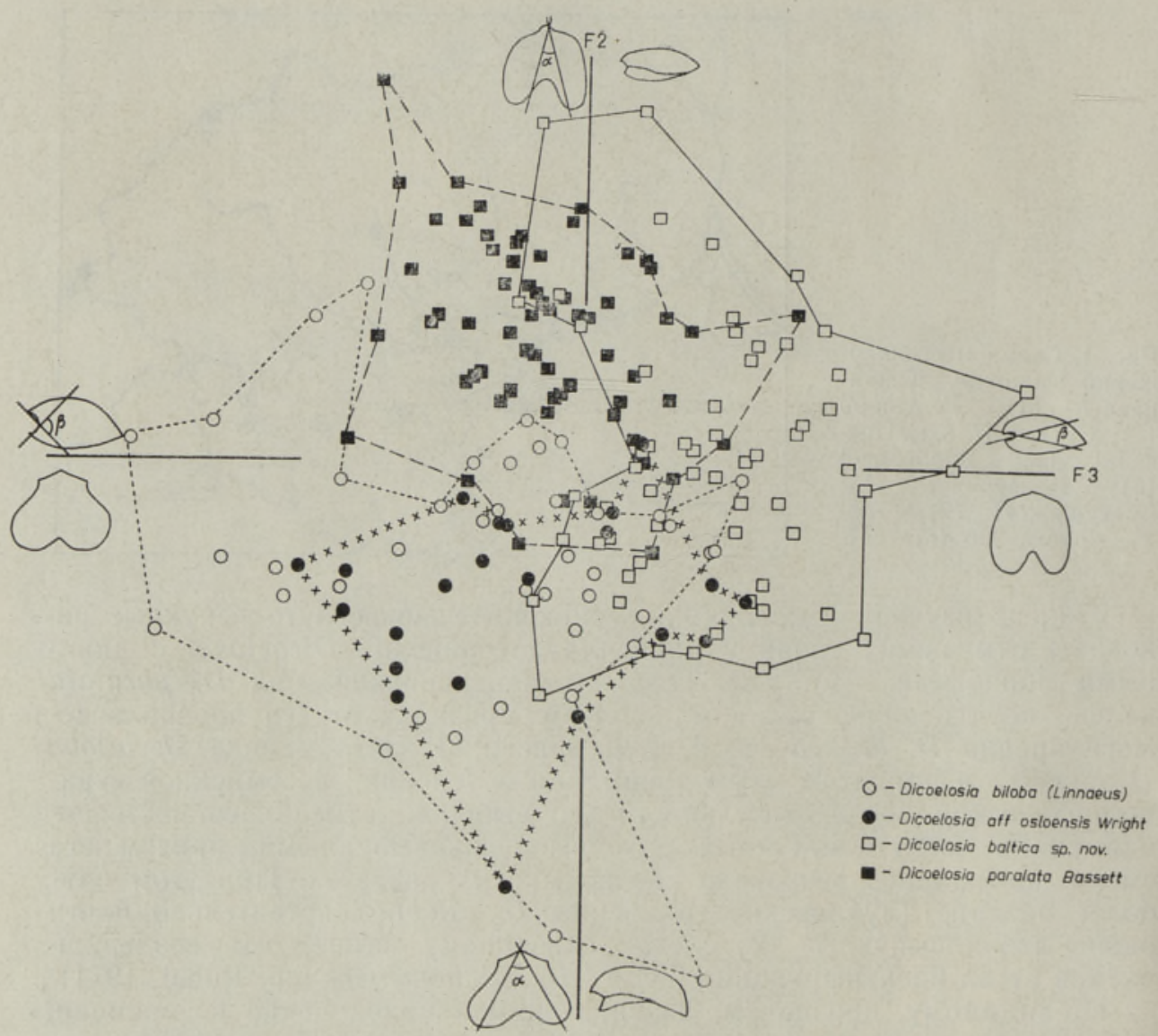

Рис. 2. Распределение экземпляров рода Dicoelosia в факторном пространстве по материалам из скважин Эстонин: Каугатума (29 экземпляров), Рухну (21), Икла (28), Хяэдемеэсте (15), Селисте (12), Пярну (2), Абья (3) и Литвы: Суткай-87 (38), Гелува-99 (9), Крякянава-7 (8) и Твярячюс-336 (1).

Выделенные виды, на основе десяти измеренных признаков, оценивались по сгруппированности экземпляров в трехмерном факторном пространстве (ср. Brower, Veinus, 1978). Согласно этому, приведенные на рис. 2 факторы $F 2$ и $F 3$ дают соответственно 19,8 и 20,6\% общей

\section{ТАБЛИЦА I}

Фиг. 1-14 Dicoelosia baltica sp. n.: 1-5 вид со стороны брюшной, спинной створок, сбоку, сзади и спереди раковины $\mathrm{Br} 3405$, голотип, $\times 6$, велизеская свита адавереского горизонта, обн. Лятикюла, Эстония. $6-8$ вид со стороны брюшной и спинной створок, сбоку раковины 14/B101, паратип, $\times 6$, швянченская свита, скв. Суткай-87, гл. 914,7 м. 9-11 вид со стороны брюшной и спинной створок, сбоку раковины 14/В102, паратип, $\times 6$, швянченская свита, скв. Твярячюс-336, гл. 209,4 м. 12,13 внутреннее строение брюшных створок, 14/В1182 и 14/B1183, $\times 7$, швянченская свита, скв. Буткунай-241, гл. 539,2 м. 14 внутреннее строение спинной створки, 14/В1185, $\times 8$, швянченская свита, скв. Буткунай-241, гл. 538,4 м. Фиг, 15-26 Dicoelosia paralata Bassett. Увеличение всех экземпляров $\times 6$ : 15-17 вид со стороны брюшной и спинной створок, сбоку раковины 14/B468, суткайские слои папреняйской свиты, скв. Суткай-87, гл. 898,6 м. 18-20 вид со стороны брюшной и спинной створок, сбоку раковины 14/В469, суткайские слои папреняйской свиты, скв. Суткай-87, гл. 898,6 м. $21-23$ вид со стороны брюшной й спинной створок, сбоку раковины 14/В470, суткайские слои папреняйской свиты, скв. Суткай-87, гл. 898,6 м. 24-26 вид со стороны брюшной и спинной створок, сбоку раковины, $14 / \mathrm{B} 474$, верхи швянченской свиты, скв. Гелува-99, гл. 996,1 м. 

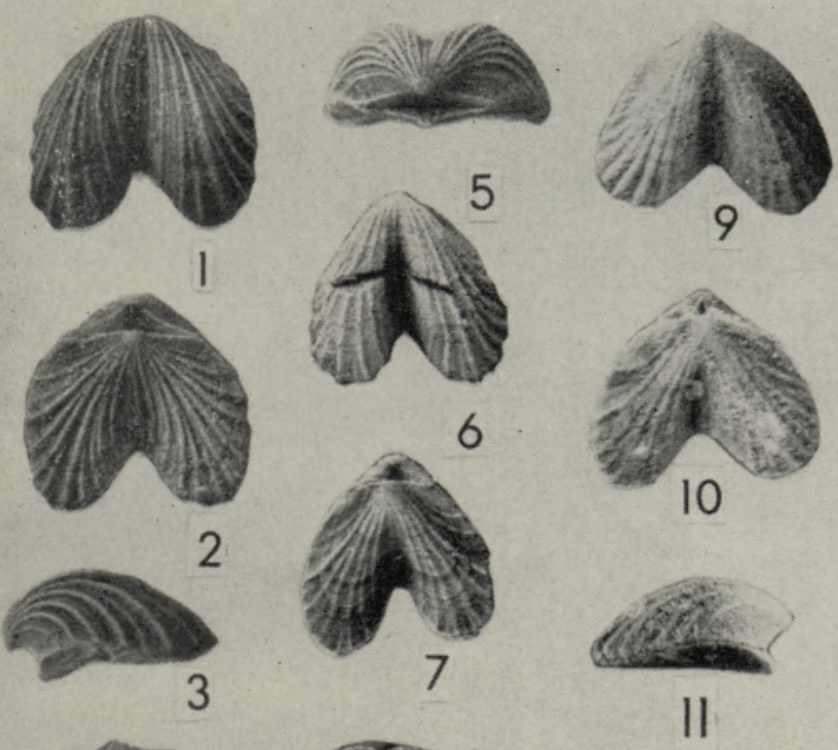

12
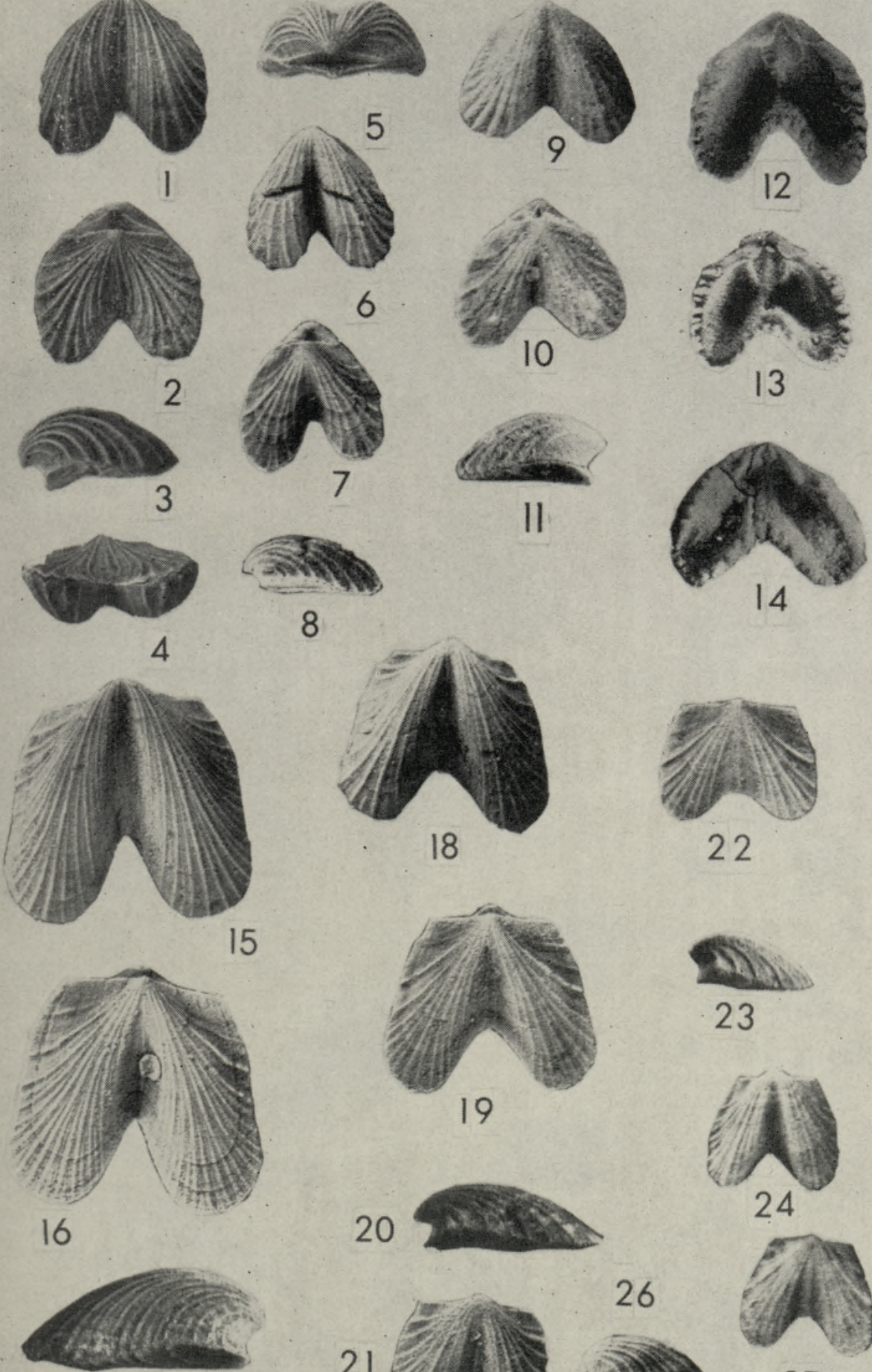

17

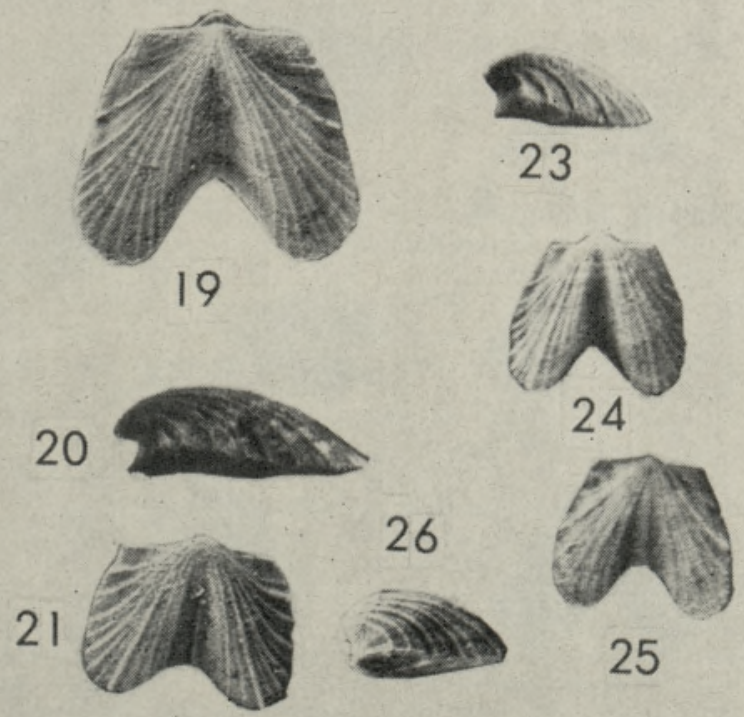



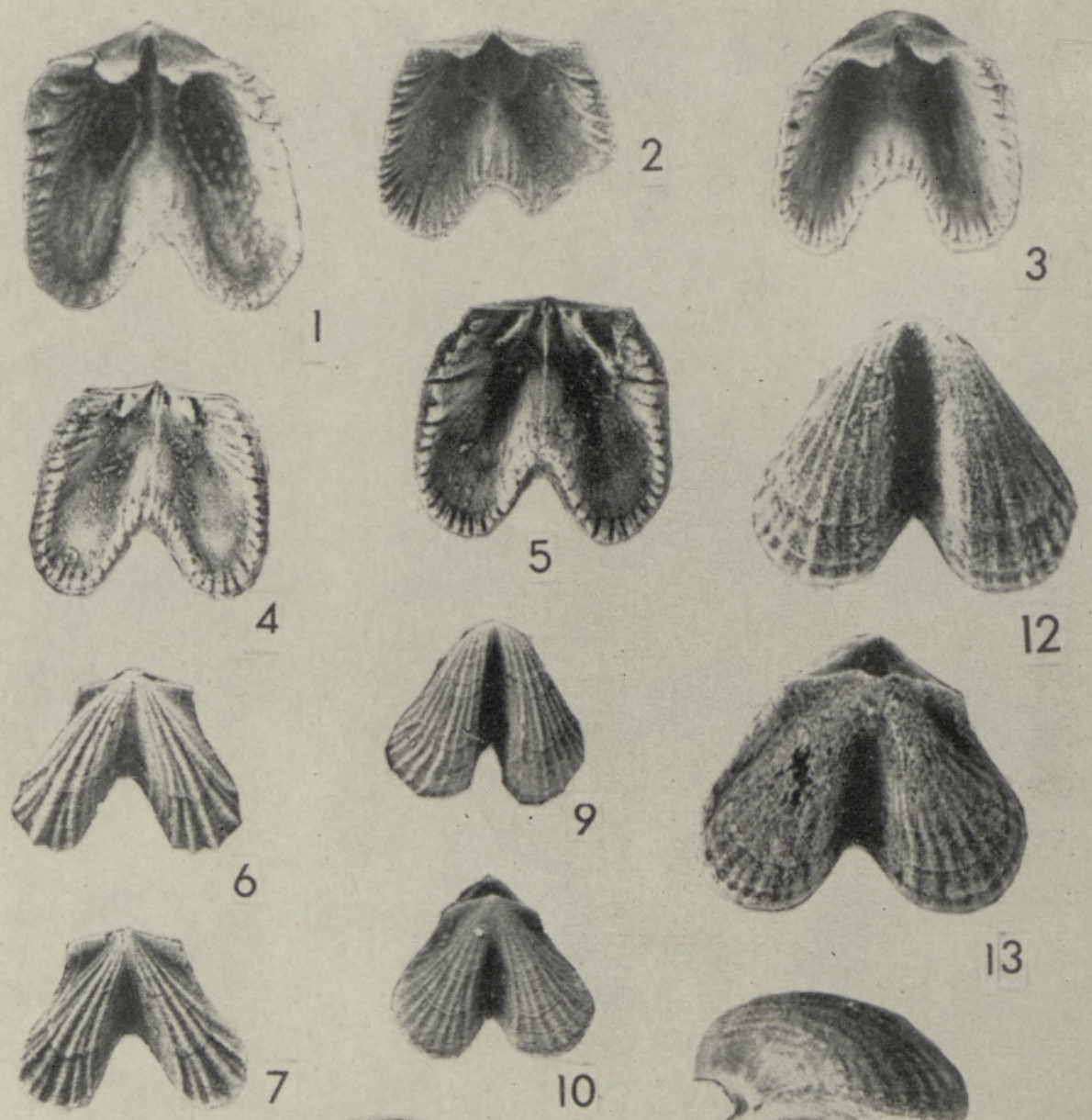

13
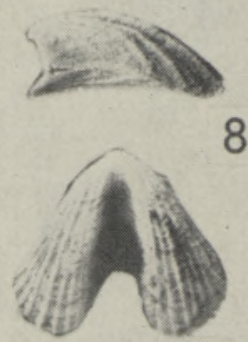

8
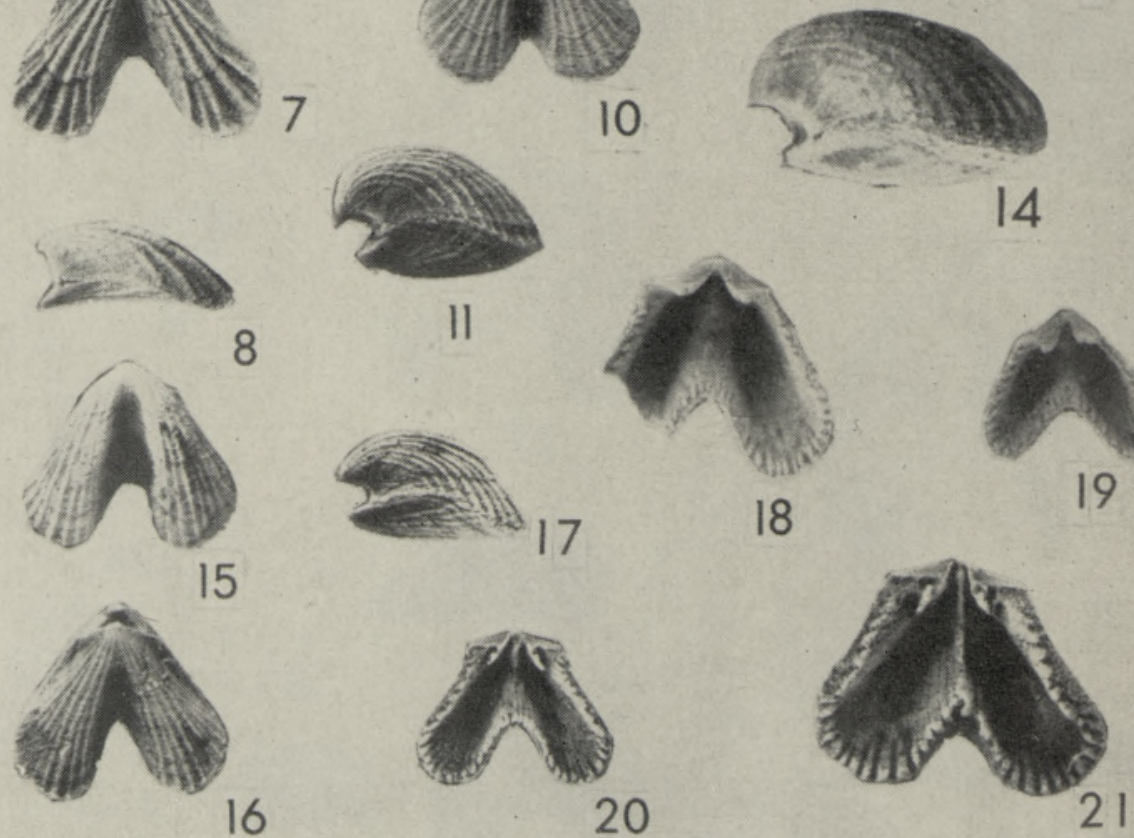

18

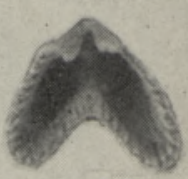

19
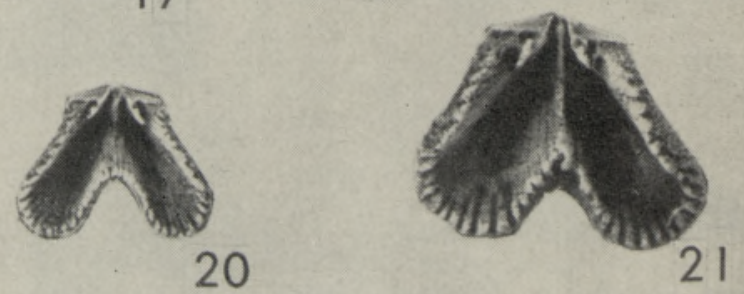
изменчивости измеренных признаков. Морфологическая интерпретация этих факторов дана непосредственно на рисунке. Здесь не рассмотрен фактор $F 1$, который интерпретирован как фактор размера и с ним тесно коррелированных признаков и который несет лишь $28 \%$ общей изменчивости. На принятом факторном пространстве ломаной линией оконтурены экземпляры, отнесенные к одному виду по визуальной оценке. При этом виды D. aff. osloensis, $D$. baltica sp. n. и $D$. paralata представлены всеми измеренными экземплярами, а вид D. biloba в основном литовскими экземплярами. Из рис. 2 следует, что: 1) изученные виды морфологически неоднородны, т. е. составляющие их выборки не всегда занимают одно и то же место в факторном пространстве; 2) установленные виды явно переходные. Однако несмотря на значительную изменчивость, почти всегда различные виды занимают достаточно разграниченные части данного факторного пространства. На основе такой морфологической разграниченности и стратиграфической обособленности выделен и новый вид $D$. baltica sp. n. Отмеченное выше поразительное сходство среднелландоверийских выборок вида $D$. aff. osloensis с видом $D$. biloba нашло закономерное отражение в перекрытии соответствуюших полей на факторном пространстве.

Семейство Dicoelosiidae Cloud, 1948

Род Dicoelosia King, 1850

Dicoelosia baltica Musteikis et Puura, sp. n.

Табл. I, фиг. $1-14$

Dicoelosia osloensis: Rubel, 1971, p. 53, pl. 8, figs 29-31; pl. 9, figs $6-10$; non pl. 8 , figs $26-28$; pl. 9 , figs $1-5,11-14$.

Г олотип. $\mathrm{Br} 3405$, велизеская свита адавереского горизонта, верхний лландовери, обнажение Лятикюла, Эстония, изображен ранее M. Рубелем (Rubel, 1971, pl. 9, figs 6-10) и здесь в табл. 1, фиг. 1-5. П а р а ти пы. 14/B101, верхний лландовери, скв. Суткай-87, глуб. 914,7 м (табл. 1, фиг. 6-8); 14/В102, швянченская свита, верхний лландовери, скв. Твярячюс-336, гл. 209,4 м (табл. 1, фиг. 9-11).

М а тери ал. 345 целых раковин, 201 брюшная и 224 спинные створки.

\section{ТАБЛИЦА II}

Фиг. 1-5 Dicoelosia paralata Bassett, скв. Буткунай-241: 1 - внутреннее строение брюшной створки 14/B414, видны отпечатки главных мантийных сосудов и точечные овариальные отпечатки; верхи швянченской свиты, гл. 521,5 м. 2 - внутреннее строение брюшной створки 14/В417, низы суткайских слоев папреняйской свиты, гл. 519,1 м. 3 - внутреннее строение брюшной створки 14/B416, верхн швянченской свнты, гл. 520,2 м. 4 - внутреннее строение спинной створки 14/B415, верхи швянченской свиты, гл. 521,5 м. 5 - внутреннее строение спинной створки $14 / \mathrm{B} 418$, низы суткайских слоев папреняйской свиты, гл. 519,1 м. Фиг. 6-21 Dicoelosia biloba (Linnaeus): $6-8$ вид со стороны брюшной и спинной створок, сбоку рақовины 14/B1117, верхи суткайских слоев папреняйской свиты, скв. Суткай-87, гл. 888,7 м. 9-11 вид со стороны брюшной и спинной створок, сбоку раковины 14/B1139, вилькийские слои папреняйской свиты, скв. Суткай-87, гл. 828,9 м. 12-14 вид со стороны брюшной и спинной створок, сбоку раковнны 14/B1153, зона Gothograptus nassa, скв. Суткай-87, гл. 792,5 м. 15-17 вид со стороны брюшной и спинной створок, вид сбоку целого экземпляра 14/В1138, вилькийские слои папреняйской свиты, скв. Суткай-87, гл. 829,8 м. 18 - внутреннее строение брюшной и спинной створок, 14/В1181, суткайские слои папреняйской свиты, скв. Суткай-87, гл. 883,8 м. 19 - внутреннее строение брюшной створки, 14/B591, верхи суткайских слоев папреняйской свиты, скв. Буткунай-241, гл. 502,1 м. 20 - внутреннее строение спинной створки, 14/B1150, внлькийские слои папреняйской свиты, скв. Суткай-87, гл. 846,4 м. 21 - внутреннее строение, спинной створки, 14/B1162, зона Gothograptus nassa, скв. Суткай-87, гл. 792,5 м. Увеличение всех экземпляров $\times 6$. 
Ди агноз. Dicoelosia средних размеров, раковина от плоско- до вогнуто-выпуклой, с выпуклыми боковыми краями; лопасти спинной створки плоские, ширина замочной линии равна примерно половине наибольшей ширины раковины.

О пи сание. Раковина средних для рода размеров, от вогнуто- до плоско-выпуклой формы с выпуклыми боковыми краями. Лопасти относительно короткие, расходятся под углом $50-63^{\circ}$. Длина раковины составляет около $3 / 4$ наибольшей ширины, длина по оси симметрии $2 / 3$ длины раковины. Замочная линия прямая, ее ширина составляет около половины наибольшей ширины раковины. Замочные углы тупые.

Брюшная створка равномерно выпуклая, с наивысшей точкой в средней ее части; макушка маленькая, загнутая. Узкий синус начинается от примакушечной части и расширяется к переднему краю, достигая 1,4 мм ширины на расстоянии 2 мм от макушки. Арея высокая, слабовогнутая, апсаклинная. Дельтирий открытый, слегка округлен у верхушки (след ножки).

Дельтириальная полость неглубокая с приподнятым дном в центральной ее части. Зубы маленькие, расположены ниже замочной линин. Зубные пластины короткие, слабо выраженные. На внутренней стороне зубов и зубных пластин отмечаются слабовыраженные круральные фоссетты. Мускульное поле сердцевидное, спереди ограничено узким низким валиком; длина его Іғочти равна ширине и составляет около $1 / 4$ длины створки. Отпечатки аддукторов узкие, расположенные на приподнятой части дна дельтириальной полости, трудно различимы от окаймляющих их отпечатков дидукторов. Последние значительно шире и немного длиннее отпечатков аддукторов. Дно створки гладкое, по краям хорошо выражены фолликулярные валики (follicular eminence, Wright, 1968).

Спинная створка плоская до слабовогнутой; лопасти уплощенные, в поперечном сечении плоские или вогнутые. Макушка едва возвышается над замочной линией. Синус неглубокий, ширина его на pacстоянии в 2 мм от макушки достигает 1,6 мм. Арея низкая, анаклинная.

Нототирий открытый, заполненный замочным отростком. Замочный отросток двухлопастный с зубчатым миофором и по-разному развитым стволом, который иногда продолжается в виде тонкой септочки на срединной приподнятой части створки. Расходящиеся брахиофоры начинаются как продолжения краев нототирия, которые к переднему краю образуют загнутые назад крючкообразные отростки (брахиофоры в узком смысле, Wright, 1968, р. 272) и оканчиваются в виде тонких пластин (брахиофоры в широком смысле, Wright, 1968, p. 273), задние части которых, соединяясь с дном створки, образуют основания брахиофоров. Длина последних составляет около $3 / 10$ длины створки. Брахиофоры расходятся под углом $70-80^{\circ}$, иногда до $90^{\circ}$. Зубные ямки маленькие, со стороны замочного отростка ограничены основаниями брахиофоров, а с переднего края - утолщениями, имеющими иногда форму фулькральных пластин. Мускульное поле двухлопастное, в виде четких углублений, занимает среднюю часть дна створки по обеим сторонам приподнятой срединной ее части. Отпечатки задних аддукторов дугообразно окаймляют удлиненные отпечатки передних. Края отпечатков в передней части мускульного поля параллельные, в задней части трудноразличимы. Дно створки тладкое с хорошо выраженной краевой кромкой фолликулярных валиков.

Внешняя поверхность створок покрыта угловатыми ребрышками, число которых увеличивается путем интеркаляции и бифуркации. Число ребер в 1 мм на расстоянии 2 мм от макушки достигает семи. На дне синуса одно или два слабовыраженных ребрышка. 
Длина

\author{
Наиболь- \\ шая шири-
} $\mathrm{Ha}$

14/B101

14/B102

Br 3405

$\begin{array}{ll}3,38 & 3,45 \\ 3,45 & 4,05 \\ 3,20 & 3,60\end{array}$

Длина по
оси сим-
метрии

2,29

2,52

2,50
Ширина

ареи

1,27

2,20

2,33
Толщина

1,26

1,61

1,41

С равнение. Описанный вид занимает промежуточное положение между Dicoelosia paralata (см. ниже) и D. osloensis (Wright, 1968, p. 309, pl. 5, figs 6-11; pl. 6, figs I, 7-10). При этом к виду D. osloensis могут быть отнесены D. aff. osloensis (Rubel, 1971, p. 51, pl. 8, figs 18-25); D. osloensis (pars) (там же, pl. 8, figs 26-28; pl. 9, figs $1-5,14) ; D$. biloba (Рыбникова, 1967, табл. 15, фиг. 1). Однако, так как перечисленные прибалтийские экземпляры морфологически весьма разнообразны, то для всех их мы применяем название $D$. aff. osloensis, в том числе и среднелландоверийские экземпляры, морфологически неотличимы от вида $D$. biloba, и раковины того же возраста с длинными лопастями, напоминающие венлокский вид D. verneuiliana (Wright, 1968, p. 312, pl. 7, figs 1-18) или лландоверийский $D$. alticavata (там же, p. 311, pl. 2, figs $11-15$ ).

Новый вид отличается от всех упомянутых более выпуклыми боковыми краями и меньшей вогнутостью опинной створки. Он же отличается от предполагаемого его потомка $D$. paralata бо́льшим углом расхождения лопастей, менее широкой замочной линией и внешним строением спинной створки: у нового вида спинная створка вогнутая до плоской, с плоским или вогнутым поперечным сечением лопастей, a у D. paralata - плоская до выпуклой, с выпуклым поперечным сечением лопастей. Боковые края у нового вида выпуклые и плавно переходят к тупым замочным углам. Боковые края раковины D. paralata почти параллельные, сходятся лишь около замочных углов. Указанные отличия четко выражены у взрослых экземпляров, размеры которых у вида $D$. paralata значительно больше, чем у нового вида. Различия молодых экземпляров указанных видов нечетко выражены.

Р аспространение. Верхи среднего лландовери - верхний лландовери Прибалтики.

Местон ахождения. Обнажение Лятикюла; скважины (в скобках глубины, м): Каугатума $(257,2-263,6)$, Рухну $(455,9-458,8)$, Хяэдемеэсте $(213,6$ - 217,3$)$, Селисте $(160,0-169,2)$, Балтынава-17 (493,0$493,4)$, Oxесааре $(358,1-366,2)$, Мурика $(42,9-17,4)$, Эйкла $(130,0-$ $130,6)$, Варбла $(137,7-148,9)$, Калвария $(844,0-846,5)$, Крякянава-7 $(845,7-837,4)$, Суткай-87 $(914,7-906,6)$, Гелува-99 (1002,2-993,7), Буткунай-241 $(545,1-532,9)$, Твярячюс-336 $(227,2-206,6)$, Вирбалис-5 $(1149,8-1122,6)$.

\section{Dicoelosia paralata Bassett, 1972}

Табл. I, фиг. 15-26; табл. II, 'фиг. 1-5

Bilobites bilobus: Венюков, 1899, с. 102, табл. I, фиг. 5; Алихова, 1954, c. 36 , табл. XXII, фиг. 3-5; Никифорова, 1954 , с. 53, табл. II, фиг. 13а, б, поп табл. II, фиг. 14а, б.

Dicoelosia biloba: Алихова, 1960, с. 192, табл. XIV, фиг. 14-15; Rubel, 1971 , pl. 10 , figs $18-22$, non pl. 9 , figs $26-31$; pl. 10 , figs $1-17$.

Dicoetosia verneuiliana: Amsden, 1968, pl. 8 , figs 1a-i; pl. 13, fig. 10b, non pl. 13, fig. 10a. 
Dicoelosia osloensis: Rubel, 1971, p. 53, pl. 9, figs $11-13$, non pl. 8 , figs $26-31$; pl. 9, figs $1-10,14$.

Dicoelosia sp. indet.: Rubel, 1971, p. 54, pl. 9, figs 20-25.

Dicoelosia paralata: Bassett, 1972, p. 60, pl. 12, figs 14-19.

Матери ал. 128 целых раковин, 80 брюшных и 81 спинная створка.

О п и сание. См. Bassett, 1972. Внутреннее строение брюшной створки такое же, как у предыдущего вида при длине мускульного поля около $3 / 10$ длины створки. Начиная с переднего края мускульного поля, на обеих сторонах срединной приподнятой части створки расположены субпараллельные отпечатки главных мантийных сосудов, которые ограничивают точечные овариальные отпечатки (табл. II, фиг. 1).

Внутреннее строение спинной створки такое же, как у предыдущего вида при длине оснований брахиофор $1 / 5-3 / 10$ длины створки и угле расхождения брахиофор 80-90. У некоторых экземпляров на срединной приподнятой части створки наблюдалась т. н. ланцетовидная арея (Wright, 1968, p. 278), разделенная тонкой септочкой, продолжением ствола замочного отростка.

Изменчи вость описанного вида проявляется в размерах, форме раковины и выпуклости спинной створки. Так, по выборке из 20 целых экземпляров (скв. Буткунай-241, гл. 521,5 м) было 11 относительно маленьких и 9 крупных. В числе маленьких экземпляры со слабовогнутыми, плоскими и слабовыпуклыми створками распределились соответственно: 6, 4 и 1. По очертанию раковины вогнутые формы $D$. paralata напоминают экземпляры вида $D$. baltica sp. n. Зато среди 9 крупных экземпляров этой же выборки вогнутые спинные створки не наблюдались - было 6 плоских, 3 слабовыпуклых. Встречаются единичные раковины с длинными лопастями типа вида $D$. verneuiliana.

Судя по литовскому материалу, более крупные и многочисленные экземпляры вида $D$. paralata приурочены к зеленоватым, более карбонатным мергелям, а в более глинистых серых мергелях их число и размеры раковин меньше.

С равнени е. Описанные литовские экземпляры, несомненно, идентичны с английскими $D$. paralata, отличаются от последних лишь незначительно большим углом $\left(41-43^{\circ}\right)$ расхождения лопастей раковины. D. paralata легко узнается среди латышских, эстонских и подольских особей (см. синонимику). К этому же виду, вероятно, следует отнести экземпляры, изображенные из мергелей Висьбю с о-ва Готланд (Amsden, 1968; pl. 8, figs 1a-i; pl. 13, fig. 10b).

Р аспространение. Верхи лландовери и низы венлока. Литвы, Эстонии, Латвии, рестевские и низы демшинских слоев китайгородского горизонта Подолии, нижний венлок Англии (Woolhope Limestone).

Местон ахождения. Скважины (в скобках глубины, м): Пренай $(605,7-609,0)$, Калвария $(841,0-837,5)$, Крякянава-7 $(834,2-833,7)$, Суткай-87 (905,8-898,8), Гелува-99 $(999,8-993,7), \quad$ Буткунай-241 $(534,0-519,1)$, Твярячюс-336 $(197,5)$.

\section{Dicoelosia biloba (Linnaeus, 1758).}

Табл. II, фиг. 6-21.

Dicoelosia oklahomensis: Рыбникова, 1967, с. 175, табл. XIV, фиг. 7,8 ; Rubel, 1971, p. 57, pl. 9, fig. 32; pl. 10, figs $23-40$. 
Dicoelosia biloba: Amsden, 1968, pl. 8, figs 3a-e; pl. 13, fig. 12a; Wright, 1968, p. 291, pl. 1, figs 1-17; pl. 2, figs 1-10; Rubel, 1971, p. 55, pl. 9, figs $26-31$; pl. 10 , figs $1-17$; non pl. 10 , figs $18-22$; Bassett, 1972 , p. 57, pl. 12, figs 1-13; Havliček, 1977, p. 210, pl. XXXV, figs $16,17$.

Материал. 444 целые раковины, 171 брюшная и 169 спинных створок.

Ол и с а н и е. См. Bassett, 1972.

Измен чи вость выражена преобладанием различных типов раковин в различных выборках. Так, в скв. Буткунай-241 на глубине 488,2 м распределение 67 целых раковин по экземплярам с выпуклой, плоской и вогнутой спинной створкой соответственно следующее: 38 , 19 и 10. Но существуют и такие выборки, где преобладают плоскоили вогнуто-выпуклые раковины.

Можно отметить, что с увеличением выпуклости спинной створки уменьшается угол расхождения и увеличивается ширина лопастей, почти исчезают ушки, уменьшается расстояние между макушками, в частности, в связи с увеличением вогнутости брюшной ареи. Кроме того, плоско- и вогнуто-выпуклые формы имеют более выраженную радиальную скульптуру, а в синусе их брюшных створок почти всегда развито срединное ребро.

Увеличение выпуклости спинной створки, несомненно, связано с ростом раковин, но преобладание одного из вышеупомянутых типов раковин в отдельных выборках, состоящих из экземпляров более или менее одинаковых размеров, указывает и на изменчивость, вызванную либо экологически, либо генетически контролируемым фактором. В данном этапе изучения прибалтийских Dicoelosia можно утверждать, что изменения в размерах и форме их раковин неоднонаправлены во времени. Мы склонны интерпретировать неоднократные превращения двояковыпуклых форм в плоско- или вогнуто-выпуклые как результат воздействия среды. Более того, преобладание относительно крупных двояковыпуклых форм в верхах венлока и низах лудлова Литвы совпадает с увеличением карбонатности пород в этой части разреза. Именно поэтому двояковыпуклые формы лудловского возраста, описанные ранее из силура Прибалтики под названием D. oklahomensis (см. синонимику), в данной работе рассматриваются как один из различных морфологических типов вида D. biloba.

Р аспространение: верхи нижнего венлока (верхняя часть зоны M. riccartonensis) - нижний лудлов Литвы и Эстонии; верхний лландовери - лудлов Латвии, венлок о-ва Готланд (Slite and Mulde Beds), венлок - нижний лудлов Британии и Богемии.

Местон ахождения. Скважины (в скобках глубины, м): Буткунай-241 (511,6-474,2), Гелува-99 (833,8-828,9), Суткай-87 (888,7$780,0)$, Калвария $(835,2-699,0)$.

\section{Л ИТЕРА Т У РА}

Алихова T. Н. Отряд Orthida. - В кн.: Основы палеонтологин. Мшанки, брахиоподы. М., 1960, 183-197.

Алихова T. Н., Балашова Е. А., Балашов З. Г. Полевой атлас характерных комплексов фауны отложений ордовика и силура южной части Литовской ССР. М., 1954 .

Венюков П. Н. Фауна силурин̆ских отложений Подольской губернин. Материалы для геологии России, т. ХIX, СПб., 1899.

Никифорова $O$. Н. Стратиграфия и брахиоподы силурийских отложений Подолии. M., 1954 . 
Решения межведомственного регионального стратиграфического совещания по разработке унифицированных стратиграфических схем Прибалтики 1976 г. С унифицированными стратиграфическими корреляционными таблицами. Л., 1978.

Рыбникова M. В. Описание брахиопод. - В кн.: Стратиграфия, фауна и условия образования силурийских пород Средней Прибалтики. Рига, 1967, 169-221.

Amsden, T. W. Articulate brachiopods of the St. Clair Limestone (Silurian), Arkansas, and the Clarita Formation (Silurian), Oklahoma. - Paleont. Soc., Mem., 1968, $1,1-117$.

Bassett, $M$. $G$. The Articulate Brachiopods from the Wenlock Series of the Welsh Borderland and South Wales. Part 2. London Palaeontogr. Soc. Mon., 1972, $27-78$.

Brower, J. C., Veinus, J. Multivariate analysis of allometry using point coordinates. J. Paleontol., 1978, 52, 1037-1053.

Havliček, V. Brachiopods of the order Orthida in Czechoslovakia. - Rozpravy Ústř. úst. geol,, 1977, 44, 1-327.

Johnson, J. G., Boucot, A. J., Murphy, M. A. Wenlockian and Ludlovian age brachiopods from the Roberts Mountains Formation of Central Nevada. - Univ. California Public. Geol. Sci., 1976, 115, 1-102.

Rubel, M. Taxonomy of dicoelosiid brachiopods from the Ordovician and Silurian of the East Baitic. - Palaeontology, 1971, 14, 34-60.

Wright, A. D. The brachiopod Dicoelosia biloba (Linnaeus) and related species. Ark. Zool., 1968, 20, N 14, 261-319.

Вильнюсский государственный университет им. В. Капсукаса

Поступила в редакцию 11/XI 1982

Тартуский государственный университет

\section{P. MUSTEIKIS, I. PUURA}

\section{BALTIKUMI SILURI BRAHHIOPOODID PEREKONNAST DICOELOSIA}

Baltikumi silurit läbivast kaheksast puuraugust pärineva arvuka kollektsiooni pōhjal on kirjeldatud liike Dicoelosia baltica sp. n., D. paralata ja $D$. biloba. Faktoranalüüsi abil on hinnatud nendevahelist morfoloogilist sarnasust. On tehtud korrektiive suunatud arengu kontseptsiooni kasutamisse vaadeldud brahhiopoodide klassifitseerimisel.

\section{P. MUSTEIKIS, I. PUURA}

\section{THE BRACHIOPOD GENUS DICOELOSIA FROM THE BALTIC SILURIAN}

Dicoelosia baltica sp. n., D. paralata and D. biloba are described from numerous collections derived from eight boreholes through the Baltic Silurian. Their morphological relationships are evaluated by means of factor analysis. The use of morphological trends in the classification of dicoelosiids is considered critically. 